\title{
Cystic fibrosis: analysis of linkage of the disease locus to red cell and plasma protein markers
}

\author{
L.-C. Tsui, ${ }^{1,3}$ D.W. Cox, ${ }^{1,2,3}$ P.J. McAlpine, ${ }^{4}$ and M. Buchwald ${ }^{1,3}$ \\ ${ }^{1}$ Department of Genetics, Research Institute, ${ }^{2}$ Department of Pediatrics, The Hospital for Sick Children, \\ ${ }^{3}$ Departments of Medical Genetics and Medical Biophysics, University of Toronto, Ontario, and \\ ${ }^{4}$ Division of Human Genetics, The University of Manitoba, Winnipeg
}

Cystic fibrosis (CF) is the most common autosomal recessive disorder in Caucasian children; it affects approximately 1 out of 2000 live-births in North America (reviewed in Talamo et al, 1983). The patients suffer from chronic pulmonary disease and pancreatic enzyme insufficiency. They also have a highly elevated level of sweat electrolytes which, although of little clinical consequence itself, is the most reliable diagnostic feature of the disease. All these symptoms are consistent with $\mathrm{CF}$ being an exocrine disorder. However, despite extensive research efforts, the basic biochemical defect in CF remains unknown.

Genetic heterogeneity has been considered as a possible explanation for the high frequency of the disease. However, all available data are only consistent with the assumption that $\mathrm{CF}$ is due to mutation(s) at a single locus (Andersen and Hodges, 1946; Steinberg et al, 1956; Danks et al, 1984; Romeo et al, 1985). It should be possible, therefore, to discover a genetic marker closely linked to the disease locus by genetic linkage studies. Previous investigators have provided evidence against close linkage of $C F$ with the genetic determinants for the ABO, Rh, K, Fy, Jk, Le, $P$ and MNS blood groups, and HLA (Steinberg et al, 1956; Steinberg and Morton, 1956; Goodchild et al, 1976). A recent report has suggested a possible linkage between F13B and CF (Eiberg et al, 1985) but the lod score is far from conclusive.

Supported by grants from the Canadian Cystic Fibrosis Foundation, Sellers Funds, Medical Research Council of Canada, and The National Institutes of Health (USA). L.-C.T. is a scholarship recipient from the Canadian Cystic Fibrosis Foundation.

Request reprints from: Dr Lap-Chee Tsui, Department of Genetics, The Hospital for Sick Children, 555 University Avenue, Toronto, Ontario M5G 1 X8 (Canada).
We have examined 11 red cell and plasma protein markers, namely ACP1, AHSG, AK1, C3, GC, IGHG, GPT, PGM1, PI, PLG, and TF, using blood samples from 26 Canadian $C F$ families each with at least two affected children. Probability of linkage between $\mathrm{CF}$ and these markers was analysed using either the LIPED (Ott, 1973) or the Mark III program (Côtèq, 1975). As shown in table I, none of these markers are closely linked to CF. However this information may be of interest to other investigators.

Table I. Linkage data for 11 chromosome marker loci and CF

\begin{tabular}{llllllr}
\hline $\begin{array}{l}\text { Marker loci } \\
\text { (chromosomal } \\
\text { location) }\end{array}$ & \multicolumn{4}{l}{$\begin{array}{l}\text { Lod (z) scores at various } \\
\text { recombination fractions }(\theta)\end{array}$} \\
\cline { 2 - 7 } & & 0.05 & 0.10 & 0.20 & 0.30 & 0.40 \\
\hline$A C P I$ & $(2 \mathrm{p} 23$ or $\mathrm{p} 25)$ & -3.382 & -1.866 & -0.658 & -0.207 & -0.040 \\
$A H S G$ & $(3 \mathrm{q})$ & -3.103 & -0.986 & 0.209 & 0.271 & 0.095 \\
$A K I$ & $(9 \mathrm{q} 34)$ & -4.334 & -2.689 & -1.180 & -0.463 & -0.109 \\
$C 3$ & $(19 \mathrm{pter}-\mathrm{q} 13.2)$ & -4.074 & -2.115 & -0.616 & -0.130 & -0.010 \\
$G C$ & $(4 \mathrm{q} 11-\mathrm{q} 13)$ & -4.150 & -2.513 & -1.066 & -0.407 & -0.095 \\
$I G H C$ & $(14 \mathrm{q} 32.3)$ & -2.848 & -0.728 & 0.490 & 0.499 & 0.186 \\
$G P T \quad(8 \mathrm{q} 13$ or & & & & & \\
$16 \mathrm{pter}-\mathrm{p} 11)$ & -2.033 & -0.966 & 0.124 & 0.089 & 0.053 \\
$P G M I(1 \mathrm{p} 22.1)$ & -5.248 & -2.563 & -0.574 & -0.013 & 0.038 \\
$P I$ & $(14 \mathrm{q} 24-\mathrm{q} 32)$ & -4.903 & -2.366 & -0.563 & -0.062 & 0.015 \\
$P L G$ & $(4)$ & -6.373 & -3.613 & -1.373 & -0.477 & -0.103 \\
$T F$ & $(3 \mathrm{q} 21-\mathrm{q} 25)$ & -7.949 & -4.575 & -1.770 & -0.619 & -0.134 \\
\hline
\end{tabular}

We thank Kenneth Kidd for providing the LIPED computes program and advice; Natasa Plavsic, Dara Kennedy, Tammy Mansfield and Diane Wills for expert technical assistance; Pat Zavitz and the following CF Clinics for assistance in collecting family blood samples: The Hospital for Sick Children, Toronto; Kitchener-Waterloo Hospital; Hôpital de Chicoutimi, Inc.; Regina General Hospital; University of Saskatchewan Hospital, Sas 
The Izaak Walton Killam Hospital for Children, Halifax; 1000; Thild Health Center, St. John's, and University of Alberta powatal, Edmonton.

wideren DH, Hodges RG: Celiac syndrome V. Genetics of cystic fbrosis of the pancreas with a consideration of the etiology. Am $\mathrm{J}$ Dis Child 72:62-80 (1946).

-iteq GB: Centromeric linkage in man. Ph.D. Thesis. Univ. of Birmingham (1975).

ynts DM, Phelan PD, Chapman C: Retraction: no evidence for more than one locus in cystic fibrosis. Am J hum Genet 36:1398-1402 (1984).

Gerg H, Schmiegelow K, Koch C, Mohr J, Schwartz M, Niebuhr E: Cystic fibrosis; hint of linkage with F13B. Clin Genet 27:206 (1985).

coodchild MC, Edwards JH, Glenn KP, Grindey C, Harris R, Mackintotosh P, Wentzel J: A search for linkage in cystic fibrosis. J med Genet 7:417-419 (1976).

wJ:A computer program for linkage analysis in human pedigrees. Am J hum Genet 24:57A (1973).
Romeo G, Bianco M, Devoto M, Menozzi P, Mastella G, Giunta AM, Micalizzi C, Antonelli M, Battistini A, Santamaria F, Castello D; Marianelli A, Marchi AG, Manca A, Miano A: Incidence in Italy, genetic heterogeneity, and segregation analysis of cystic fibrosis. Am J hum Genet 37:338-349 (1985).

Steinberg AG, Morton NE: Sequential test for linkage between cystic fibrosis of the pancreas and the MNS locus. Am J hum Genet 8:177-189 (1956).

Steinberg AG, Schwachman H, Allen FH, Dooley RR: Linkage studies with cystic fibrosis of the pancreas. Am J hum Genet 8:162-176 (1956).

Talamo RC, Rosenstein BJ, Berninger RW: Cystic Fibrosis, in Stanbury JB, Wyngaarden JB, Fredrickson DS, Goldstein JL, Brown MS (eds): The Metabolic Basis of Inherited Disease, 5th edition, pp 1889-1917 (McGraw-Hill, New York 1983).

Accepted: 9 May 1985 